\title{
5 German-Ottoman Rapprochement Policy and its Impact in Libya during World War I (1914-1918)
}

The German-Ottoman policy of rapprochement and its impact on the situation in Tripoli during World War I (1914-1918) starts with a different approach of the German and Ottoman policy toward Britain and France and their ambitions in the Mediterranean. This is a significant turning point in international politics. Therefore, it is important to examine the German position toward the Libyan jihad, with special emphasis on German motives and goals in supporting the Ottoman Empire, and the presence of Germany in Libya. This was after an explicit announcement by Germany that it would play a more active role in the political developments of the country by supporting the Libyan national movements. Here, they concentrated their support on two main currents of nationalism; the movement headed by Ramaḍān al-Swīḥlī (1879-1920) and Sulaymān al-Bārūnī in the west, and the al-Sanūsìyya in the east. ${ }^{1}$ Sulaymān al-Bārūnī, who came from a relatively distinguished family and represented the area of the Western Mountains, tried to organize a force to oppose the Italian landings, but did not receive the support of the Ottoman government. ${ }^{2}$ Germany supported the Ottoman Empire in the revival of its influence in Libya. This development led to the declaration of war against the British in Egypt in 1915 according to the German-Ottoman geostrategic project that aimed to weaken the power of the British in the Mediterranean, maining battles of the Ottoman war against the British in Egypt. An examination of the German policy toward Libya at the end of the First World War in 1918, and an analysis of how this was reflected in international developments on the orientation of the policy in Libya is to be understood in the light on what was going on in this part of Africa. How the defeat of Germany and the Ottoman Empire in World War I led them to abandon their project in Libya and the region?

\section{World War I}

World War I is seen as an influential event in the history of the world as it included the major powers and took place on different continents. The beginning of

1 Politisches Archiv des Auswärtigen Amts, Allgemeine Angelegenheiten von Tripolis, R16106 Nr. A33454, 9/12/1916; on Ramaḍān al-Swịhlī see St. John, Ronald B., Historical Dictionary of Libya, Toronto, 2014, p. 316.

2 Childs, Timothy W., Italo-Turkish Diplomacy and the War over Libya 1911-1912, Brill, Leiden, 1990, p. 89. 
World War I was when the heir to the Austro-Hungarian throne was assassinated on June 28, 1914, and the government in Austria declared Serbia to have been involved, starting hostilities after refusing any sort of negotiation. ${ }^{3}$ The major powers, mainly Russia, Germany, France, and Britain, joined the war, which developed into a world war. ${ }^{4}$ It is argued in the literature that the major causes of World War I were economic imperialism, in terms of extending colonies outside Europe and driven by the Industrial Revolution. Other factors included the nationalism movements and the system of secret alliances and agreements that divided Europe into two main blocs. ${ }^{5}$ One was the Triple Alliance of Germany, Austria-Hungary, until May $1915 .^{6}$ The other alliance was France, Russia and Great Britain; later, Italy announced that it would join the Allies. In 1914, with the outbreak of the First World War, the world was divided into two camps. The Ottoman Empire later joined the alliance of Germany and Austria-Hungary. In addition to these two alliances, there were many other alliances and agreements signed secretly or publicly between the major powers, and included other countries. $^{7}$ Moreover, one of the main causes of World War I was the desire of the major powers to expand their navies and military forces and control more territories. As the war continued, the smaller countries and states joined these two main powers in accordance with their political and economic interests. As Koller states, the fighting extended rapidly to several other countries including Japan, Belgium, New Zealand, and South Africa, which joined the German colonies in Africa, Asia and the Pacific. ${ }^{8}$ The Ottomans decided to enter the war on the side of Germany on October $29,1914^{9}$ after signing a military contract with Germany on October 27, 1913. The contract stipulated that Germany would take over the reform of the Ottoman military forces. ${ }^{10}$ This was a step taken by Grand Vizier and Minister of War Mahmud Shevket Pasha (1856-1913), who was trying

3 Hamilton, Richard F., and Holger H. Herwig (eds.), The Origins of World War I, Cambridge University Press, Cambridge, 2003, p. 10.

4 Ibid., p. 12.

5 Ibid., p. 16.

6 Straub, Eberhard, Weltgeschichte im 20. Jahrhundert. Daten, Fakten, Dokumente in chronologischem Überblick, Drömer Knaur, Munich, 1985, p. 58

7 Hamilton and Herwig, The Origins of World War I, p. 10.

8 Koller, Christian, "The Recruitment of Colonial Troops in Africa and Asia and their Deployment in Europeduring the First World War", Immigrants \& Minorities, vol. 26, no. 1-2, March/July 2008, pp. 111-133.

9 Uyar, Mesut and Edward J. Erickson, A Military History of the Ottomans: From Osman to Atatürk, Praeger Security International, Santa Barbara, California, 2009, p. 243.

10 Ibid., p. 237. 
to restore the Ottoman Empire, which was collapsing due to the loss of several territories and much power in the Ottoman-Italian War of 1911 and the Balkan Wars of 1912-1913. ${ }^{11}$ Part of the efforts of the Germans and the Ottomans was to mobilize as much support for their entrance into the war as possible. To this end, the policy-makers in the Ottoman Empire promoted the idea of Islamic holy jihad and asked the Islamic countries, especially those under their control, to join them on this basis. It seems likely that this strategy was developed in response to a suggestion by an official at the German Embassy in Cairo, von Oppenheim. ${ }^{12}$ By invoking the concept of jihad, the Germans hoped to mobilize more Muslim support for their efforts against the Russian, ${ }^{13}$ British and French forces in the region. ${ }^{14}$ Thus, the propaganda of the German and Ottoman Empire began to be directed toward Libya per German-Ottoman plans that had been prepared earlier. The first step was the declaration of jihad against Britain, France and Russia issued by the Ottoman Sultan Mohammad V (1844-1918). ${ }^{15}$ He then used a fatwa ${ }^{16}$ provided by the Shaykh al-Islam in Istanbul supporting the necessity of jihad to the path of God against the enemies of religion, particularly when these had taken control of Islamic countries. ${ }^{17}$ Thus, a set of messages and letters was prepared and addressed to the leaders of jihad in those countries, including Libya, which occupied an important place in German-Ottoman military plans at that time due to its strategic location. ${ }^{18}$

The Turkish authorities worked hard on this project and presented it to the Arab politicians residing in Turkey. These included the Libyan Bashīr al-Sa'adāwī, and the Shaykh Ṣaleḥ al-Tūnisī, Moḥammad Farīd and 'Alī Pash Ḥāmbah, and others. These individuals, who made up a committee called Lajnat Tashkilāt

11 Ibid., p. 236.

12 Hagen, Die Türkei im Ersten Weltkrieg, p. 13.

13 Lüdke, Tilman, “(Not) Using Political Islam: The German Empire and its Failed Propaganda Campaign in the Near and Middle East 1914-1918 and Beyond”, in Zürcher, Erik-Jan, Jihad and Islam in World War I: Studies on the Ottoman Jihad on the Centenary of Snouck Hurgronje's "Holy War Made in Germany”, Leiden University Press, Leiden, 2016, p. 83.

14 Lüdke, Tilman, Jihad Made in Germany: Ottoman and German Propaganda and Intelligence Operations in the First World War, Lit, Münster, 2005, p. 45.

15 Wathīqā 46, al-Wathā'iq al-ițālīyya, p. 163; for an overview see Stoddard, Philip Hendrick, "The Ottoman Government and the Arabs, 1911 to 1918”, PhD dissertation, Princeton University, 1963.

16 A legal opinion or learned interpretation by a qualified jurist or mufti given on issues pertaining to Islamic law; Hallaq, Wael B. "Fatwa", in Encyclopedia of the Modern Middle East and North Africa, Encyclopedia.com

17 Hagen, Die Türkei im Ersten Weltkrieg, p. 190.

18 See Micheleta, Luca and Andrea Ungari, L'Italia e la guerra nella Libya, Storia Studium, Roma, 1974, 490p. 
Makhșūṣa, headed by Sulaymān al-'Askarī, were amongst the most prominent political personalities of the period and were considered essential to supporting the propagation of the idea of jihad. Mohammad Farīd was the head of the Egyptian Nationalist Party (al-Hizb al-Wațañ al-Miṣñ), while 'Alī Pash Hāmbah and Saleh al-Tūnisī were leaders in a Tunisian movement calling for the removal of the French occupation there. ${ }^{19}$ The idea was approved by the majority, except for Bashīr al-Sa'adāwī, who justified his reservations on the grounds that the mujāhidīn in Libya were not in a position to confront the British and the Italians at the same time, and that it would be better to expel the Italians before approaching the British. However, the enthusiasm of the others for the idea, and the support of Enver Pasha who in 1914 showed great confidence in the successful outcome of the idea, led them to send a message to Sayyid Ahmed al-Shariff urging him to stand by the Ottoman Empire and to declare war on its enemies. A number of letters were sent for this purpose, particularly to Sayyid Ahmed al-Sharîf, who led the war in eastern Libya against the Italians. The letters encouraged him to support the plans to weaken the British military presence in Egypt from the Libyan side of the border. At the same time, they requested Enver Pasha from Bashīr al-Sa'adāwī to accompany the Ottoman officers to Tripoli, but he apologized because the duty did not precisely conform to his political stances toward this work. ${ }^{20}$ The Germans and the Ottomans tried to support jihad movements in many Arabic countries where the allies ruled, including Egypt, Tunisia, Morocco, and Libya. In the next part of the chapter, their support for the al-Sanūsìyya movement to fight the British in Egypt, instead of fighting the Italians in Libya, is illustrated.

\subsection{German-Ottoman Support to the al-Sanūsīyya Movement}

The Ottoman Empire decided to revive its influence in Libya in 1914. The Libyan population responded positively to the renewed interest of the Ottoman Empire. ${ }^{21}$ This gave Germany, as an Ottoman ally, more opportunity to develop its own presence in the region. The decision of the Ottomans to revive their influence in Libya was supported by the German government, which wanted to reduce the control of the allied nations everywhere. The methods they chose to achieve this

19 Hūwīdī, al-Ḥaraka al-wațanìyya fĩ sharq Lìbiyā, p. 52; Shukrī, Mīlād dawlāt Lìbiyā al-ḥadìthā, p. 245.

20 Shukrī, Mīlād dawlāt Lībiyā al-ḥadīthā, pp. 460-461.

21 Ibid. 
goal included spreading unrest and military skirmishes and supporting revolts against the European powers, particularly in the Arab countries, e.g., the British in Egypt, and to increase the level of resistance against the Italian occupation in Libya. ${ }^{22}$ Meanwhile, there were two main factions within the Libyan jihad movement. The first of these was the Western Independent Libyan Movement, which was led by Ramaḍān al-Swīḥlī and Sulaymān al-Bārūnī and was based in Misurata. The second was al-Sanūsīyya movement led by Sayyid Aḥmed al-Sharîf al-Sanūsī in the eastern region of the country. ${ }^{23}$ The debate within the German political field was about which of two factions Germany should support and which would be more beneficial to German-Ottoman interests. ${ }^{24}$ The decision was finally taken to support the al-Sanūsìyya movement, by supplying them with ammunition and weapons in $1915 .{ }^{25} \mathrm{Al}$-Sharif had been recognized by the Ottoman Empire and was even granted the title of deputy sultan in the region by the Ottoman sultan ${ }^{26}$. He was also visited by Enver Pasha at the movement's headquarters in the southern part of the country, in al-Jaghbub, andwas handed the decision issued by the sultan appointing him as his deputy and conferred the leadership of the region in Libya. ${ }^{27}$ The same period also witnessed the arrival of Nuri Bey, an emissary of his brother, Enver Pasha, and Jā'far al-'Askarī, an Ottoman officer of Iraqi origin, ${ }^{28}$ who arrived on board a German submarine that docked in the port of Bardia (al-Burdi/Burdija) on the east coast of Libya in December 1914. ${ }^{29}$ The Ottoman authorities sent with them the higher ranked medals as well as a senior medal to Sayyid Ahmed al-Sharif and other members of the al-Sanūsiyya movement. ${ }^{30}$ They held a meeting attended by these parties as well as some al-Sanūsīyya chieftains and advisers of Sayyid Ahmed al-Sharīf at the end of 1914. The discussion was about the establishment of a Muslim state in North Africa supported by Germany and the Ottoman Empire. The Ottoman

22 Yāghì, al-Dawlā al- 'ūthmānìyyā fĩ al-tārīkh al-islāmī, p. 317.

23 On the Sanūsìyya movement see Vandewalle, Dirk, A History of Modern Libya, Cambridge, 2012, pp. 17-25; On the Sanūsīyya see Triaud, Jean-Louis, La légende noire de la Sanûsiyya, op.cit.; and also Triaud, Jean-Louis, Tchad 1901-1902. Une guerre franco-libyenne oubliée?, op.cit.

24 Politisches Archiv des Auswärtigen Amts, Allgemeine Angelegenheiten von Tripolis, Bd. 17, R16122, Nr. A33454, 9/12/1916.

25 Ibid.

26 Osmanli Belgelerinde: Trablusgarb, 2013, p. 577.

27 Politisches Archiv des Auswärtigen Amts, Allgemeine Angelegenheiten von Tripolis, Bd. 17, R16122, Nr. A33454, 9/12/1916.

28 Wathīqā 47, al-Wathā’iq al-ițālīyya, p. 166.

29 Shukrī, al-Sanūsìyya dīn wa dawlā, p. 247.

30 Wathīqā 49, al-Wathā’iq al-ițālìyya, p. 179. 
Sultan addressed an appeal to Sayyid Ahmed al-Sharif to support the declaration of holy war against the British, Italians, French and Russians, alluding to the serious situation that might result from the control of these countries over the Islamic world, and added that this would weaken the power of Islam. ${ }^{31}$ Therefore, religion obliged him to fight these enemies. Sultan Mohammad V (ruled 19091918) also tried to influence Sayyid Ahmed al-Sharif by sending him a letter praising the founder of the al-Sanūsìyya movement, and mentioned his efforts to protect Islam and the respect that the al-Sanūsìyya movement enjoyed in Libya and the Muslim world. ${ }^{32}$ The Sultan did not fail to mention Germany in this letter in which he confirmed the country as a friend to the Muslims and a God-given means to reform the situations of their countries. He added that this was a real opportunity to get rid of the occupation of the Italian, French and British alike. The sultan had pointed out that their declaration of jihad would lead the rest of the peoples in North Africa to follow them, enabling them to obtain freedom and all their rights. ${ }^{33}$ Most people supported the idea of Muslim jihad against the infidels, especially in light of the assistance promised by Germany. ${ }^{34}$ Germany was able to send a group of German and Turkish officers to the mujāhidin camps in eastern Libya in November 1914 to train the mujāhidin on the use of weapons. Moreover, the Germans provided them with submarines, which were the most effective weapon during this stage of the war, due to their ability to move more freely and in accordance with a schedule and well-studied plans. Germany relied heavily upon the use of submarines during World War I, both in military operations and as a safe means of communication between them and their allies. The submarines were also used to transfer arms and military equipment, and for the transport of soldiers to and from the shores of Libya. ${ }^{35}$ Some submarines were well known, such as the submarines UC20, UC73, and UC12, which was rebuilt in August 19, 1912 and began its activity toward the Libyan coast in early December 1915. The German submarines started their journey from Cattaro (Adriatic Sea) to the port of al-Burdi (Burdia/Burdija) and then returned to transfer materials and equipment to be used by the Libyans and Ottomans. ${ }^{36}$ In addition, Germany pro-

31 Mannā', Moḥammad 'Abd al-Razāq, Aḥmed al-Sharīf ḥayātahu wa jihādahu, mu'assasat nāṣir li-l-thaqāfa, Dār al-Waḥda, n.d., p. 70.

32 Hagen, Die Türkei im Ersten Weltkrieg, p. 200; Osmanli Belgelerinde: Trablusgarb, p. 577.

33 On the jihad and Germany see the work of Tilman, Jihad made in Germany, 251p; Hagen, Die Türkei im Ersten Weltkrieg, pp. 200, 203.

34 Hūwīdī, al-Haraka al-wațanìya fī sharq Lìbiyā, pp. 52-53.

35 U-Boote der Kaiserlichen Marine an der Libyschen Küste 1915-1918, pp. 1-5; see Microfiche Copex HDP13, LOS 4, Asw A-+, Politisches Archiv WK Nr. 11u, 134277 (73), 14. November 1915.

36 U-Boote der Kaiserlichen Marine an der Libyschen Küste 1915-1918, p. 1. 
vided financial aid and other assistance to the Ottomans and the Libyan mujāhidin in that area. They created the impression that the aid was sent by the Ottoman Empire ${ }^{37}$ to provide the appropriate environment for the Ottomans to work and to gain respect from the mujähidinn. ${ }^{38}$ In this context, the German and Ottoman efforts were focused more on fighting the British in Egypt. Otto Mannesmann was selected by the German political leadership to support their goals in Libya. ${ }^{39}$ Mannesmann was one of the intelligence officers of the German army and became the German consul in Libya in October 1914, arriving there in December $1914 .{ }^{40}$ It is worth mentioning that Otto Mannesmann was fully aware of the situation in North Africa because he was living in Morocco, where he oversaw the management of Mannesmann industrial businesses, of which he was an owner. He also owned large farms in the area of Sus in the south of Morocco and had strong relations with the tribal leaders. ${ }^{41}$ Thus, he had extensive experience in dealing with the Arabs and their leaders. Mannesmann had proposed to the German Ministry of Foreign Affairs to send a special delegation consisting of Ottoman and German representatives to Sayyid Ahmed al-Sharīf. ${ }^{42}$ Permission was given by the German Ministry of Foreign Affairs for the preparations described in the report of the military command in Tripoli. ${ }^{43}$ Upon receiving the approval of the ministry, preparations for the delegation began, with a focus on selecting people with high capabilities and skills in persuasion to strengthen the idea of the struggle against the British in Egypt, but not the Italians in Libya. The Germans took this action because they were aware of the rapprochement between Sayyid Idris al-Sanūsī and the British. Thus, careful preparation was taken to ensure the success of this delegation. This also required extensive communication with all the parties involved, which was the reason for the reconstruction of a telegraph station in Misurata. The construction was undertaken by German experts under the supervision of Oberleutnant von Todenwarth. ${ }^{44}$ In 1914, Otto Mannesmann arrived in the eastern part of Libya to support the al-Sanūsìyya movement and the Ottoman pre-

37 Wathīqā 48, al-Wathā'iq al-ițālīyya, pp. 175-176.

38 Hūwīdī, al-Haraka al-wațanīyya fì sharq Lìbiyā, p. 72.

39 Ibid.

40 Ghānim, 'Amalīyyat al-ghūwașāt al-'almānīyya fī al-miyāh al-lībiyyā, pp. 41, 45.

41 Ghānim, wa Shlūtir, "al-Qunșuliyya al-'almānīyya fĩ Ṭarābulis”, p. 10.

42 Sayyid Idris al-Sanūsī was also present in the region, Idris al-Sanūsī was supposed to be the leader of the al-Sanūsīyya movement but, because he was young, the position had been assigned to his cousin Sayyid Ahmed al-Sharif until Sayyid Idris became eligible.

43 Politisches Archiv des Auswärtigen Amts, Allgemeine Angelegenheiten von Tripolis, Bd. 17, R16122, Nr A33454, 9/12/1916.

44 Ibid. 
sence in the region and to serve the strategic interests of Germany. ${ }^{45}$ He had been sent as part of German-Ottoman plans to fight the British in Egypt. Mannesmann was sending his reports to the German military leaders. ${ }^{46}$ He was accompanied by the Turkish commander Nuri Bey. The political significance of their presence in the eastern part of Libya led to discussions about German intervention in Libya within the German Foreign Ministry. ${ }^{47}$ The leadership team of the military and political department there was given the responsibility of studying the situation in Libya, in general, and the military situation, in particular. The study was based on information and reports from Libya, especially those derived from the reports of Mannesmann, Oberleutnant von Todenwarth and a third person who was an informant working as an interpreter, referred to as Salama. Salama, who receives no further identification in the reports, appears to have been an Arab and evidently had a great deal of knowledge of the region. The German policy was centered on the Libyan jihad movement and how to use it to German strategic benefit. Mannesmann contacted Sayyid Ahmed al-Sharîf personally, and mentioned that they were going to award him with a senior medal from the German emperor and a book selected by him. ${ }^{48}$ The Italians were present in Libya during this time, but had withdrawn their troops to the coastal areas, where they were mainly concentrated in the cities of Tripoli, al-Khums and Benghazi. The Italians placed weak control over some ports like al-Burdi (Burdia/Burdija), Sirte, which provided important docking points for German submarines. ${ }^{49}$ The Italians also worked to strengthen their relations with Britain in Egypt to put more pressure on the mujāhidin in the eastern part of the country. ${ }^{50}$ In April 1916, the Ottoman Empire sent Sulaymān al-Bārūnī to Libya as a governor on behalf of the Ottoman sultan. ${ }^{51}$ al-Bārūnī traveled from Istanbul to Vienna and then to Libya. His journey took place under the auspices of the German government, which provided al-Bārūnì with a German submarine for the last stages of the journey, until his arrival in the city of Misurata. ${ }^{52}$ al-Bārūnī was carrying with him the decision of his appoint-

45 This finding is supported by a document in the German Political Archive containing information for which Mannesmann is described as the source. See Politisches Archiv des Auswärtigen Amts, Tripolis, vom 15. Februar 1914 bis 31. Oktober 1915, R16120, Nr. A33454, 9/12/1916.

46 Ibid.

47 Ibid.

48 Ibid.

49 al-Zāwī, Jihād al-abțāl, p. 303.

50 Ibid.

51 al-Turkī, Fuṣūl fī tārīkh al-ḥaraka al-wațanìyya al-tūnīsìyya, p. 69.

52 Politisches Archiv des Auswärtigen Amts, Allgemeine Angelegenheiten von Tripolis, Bd. 17, R16122, Tripolis, Nr. A27104. 
ment as a deputy of the sultan in the west, as well as money and weapons that had been provided by the Ottoman Empire. ${ }^{53}$ Sulaymān al-Bārūnī was able to reorganize the mujāhidin, and led a movement of struggle against the Italians, which continued through $1917 .^{54}$

\subsection{Attack on the British Army in Egypt and Battles with the Libyan Mujāhidīn in 1915}

Meanwhile, the German-Ottoman propaganda to declare jihad had begun to spread worldwide. However, a decision could not be taken by Sayyid Ahmed al-Sharif, who wanted to wait to make an appropriate decision. He wanted to continue the war against the Italians and wished at the same time to secure the help of the Ottomans and the German for his own goals. ${ }^{55} \mathrm{His}$ relations with the British were not hostile but were characterized more as being cautious. The two sides did not share the same aims or political direction but, in some cases, the British did permit aid coming from Egyptian sources to pass over the border to the mujāhidin in Libya. ${ }^{56}$ Apart from Tunisia, this had become the only means by which they could gain access to any form of assistance. ${ }^{57}$ In addition, Britain had also begun to improve their contact with Sayyid Ahmed al-Sharif, as they recognized the danger constituted by the German-Ottoman presence on the eastern borders of Libya. The British tried to persuade him to join their side to ensure that there would be no more disturbances in the western border region of Egypt. ${ }^{58}$ Sayyid Ahmed al-Sharif was frequently visited by messengers of the British offering their friendship and, at times, alliances. The messages sent by Lord Kitchener, the commissioner of the British in Egypt addressed to Sayyid Ahmed al-Sharif carried expressions of respect and appreciation of the British and indicated at the same time the importance of his position for them, as well as the British desire for friendship and mutual support. It was a clear attempt to induce him to their side. ${ }^{59}$ This was after they had learned about the presence of Turkish envoys sent to sign an agree-

53 al-Zāwī, Jihād al-abțāl, p. 303.

54 Ismā'īl, Tārīkh Afrīqiyā al-ḥadìth, p. 453.

55 De Candole, E.A.V, The Life and Times of King Idris of Libya, Ben Ghalbon, Manchester, 1990, p. 27.

56 Hūwīdī, al-Ḥaraka al-wațanìyya fì sharq Lìbiyā, p. 72.

57 Ibid.

58 Wathīqā 48, al-Wathā’iq al-ițālìyya,p. 174.

59 Mannā', Aḥmed al-Sharīf, p. 53. 
ment with Sayyid Aḥmed al-Sharīf and ally with him against Britain and Italy. ${ }^{60}$ They tried to gain time and to keep Ahmed Al-Sharif out of Ottoman-German influence so as not to offer strategic support. ${ }^{61}$ Therefore, Sayyid Ahmed al-Sharîf was hesitant to help Germany and the Ottomans at the beginning; in addition, he was aware of the extensive preparations that attacking the British in Egypt would require, including large quantities of equipment and military assistance. Given that the mujāhidin were constantly involved in smaller conflicts with the Italians, it was a matter of concern as to whether this degree of preparation was possible. Meanwhile the British imposed a tight control on the Libyan-Egyptian border and the Libyan-Sudanese border. This hampered the progress of convoys loaded with ammunition and weapons coming to Libya. There was then a crippling blockade on the country. ${ }^{62}$ The situation was further complicated by the British prevention of many Egyptian volunteers (mutațawi ūn) leaving to Libya. These volunteers tended to come from the regions of Egypt close to the Libyan border and many of them originated from tribes with Libyan origins. ${ }^{63}$ They were inspired by the idea of jihad against European occupation and decided on this basis to make their way to the camps of the Libyan mujāhidin and to join their battle against the British. ${ }^{64}$ This was particularly prominent following the Ottoman Empire's entry into the war in 1914 on the side of Germany, and its declaration of jihad against the allied forces. Given the religious and Islamic principles with which Sayyid Ahmed al-Sharīf had been educated, it would have been difficult for him to relinquish his support of the Ottoman Empire, especially when it had raised the banner of Islam and jihad. There was a religious and moral obligation to respond to this appeal, despite the risks that this would entail.

Ahmed al-Sharif was advised by some not to support the German and Ottoman plans. These people included Sultan Hussein Kamel, the Sultan of Egypt, Henry McMahon, the viceroy of the British king in Egypt, and the commander of the British army in Egypt, General Maxwell. Maxwell also offered British help in obtaining Libyan independence; therefore, Sayyid Aḥmed al-Sharif refused the German-Ottoman offer. The Ottomans reacted using their diplomatic relations to ignite fighting on the eastern front of Libya. They realized that Sayyid Ahmed al-Sharif did not want to commit his men to a war that would not help the Otto-

60 Wathīqā 289 /56219, Wathā'iq al-arshīf al-injīīizī shu'bat al-wathā’iq al-ajnabīyya, al-markaz al-wațanī li-l-māḥafūọāt wa al-dirāsāt al-tārīkhiyya, Ṭarābulis.

61 Ibid.

62 Mannā', Ahmed al-Sharîf, p. 52.

63 Hūwīdī, al-Ḥaraka al-wațanìyya fī sharq Lìbiyā, p. 72.

64 Mīkhā'ìl, al-'Ālāqāt al-injìlizìyya al-lìbiyyā, p. 54. 
mans in their fight against the Italians. It was obvious that Sayyid Ahmed al-Sharif failed to determine his position once and for all. The difficulty increased for him when he realized that the German Ottoman plans included temporarily stopping the jihad against the Italians in Libya. At that time, the idea of a truce between the mujāhidin and Italy was raised to concentrate all the forces on the war against the British in Egypt. ${ }^{65}$ Nuri Bey sent a letter to his brother Enver Pasha, referring slightingly to al-Sharif's lack of commitment to his own country and to his close relationships with the British. ${ }^{66}$ Al-Sharīf's rejection did not prevent Nuri Bey and Jā'far al-'Askarī from mobilizing and training fighters and volunteers in far eastern Libya. These fighters were from the area of Cyrenaica. They were joined by many from the 'Aūwlad 'Alì tribe, who inhabited the Egyptian desert and who traced their origins to the region of eastern Libya. The Ottoman officers wanted to guarantee the success of this project, which is why they began to receive German arms via German submarines in the Mediterranean Sea (see Appendix 5 and 6) ${ }^{67}$ All these pressures led Sayyid Ahmed al-Sharif to decide for war against the British in Egypt; ${ }^{68}$ especially after the intensive Turkish propaganda led by Jā'far al- 'Askarī, who used all the human and financial resources available to improve conditions on the Libyan-Egyptian border. He also worked to win the support of many Libyan mujāhidin who were under the influence of this idea. This prompted some of them to attack effectively on Egyptian territory without the knowledge of the al-Sanūsīyya military leadership in Libya, which did not leave any other choices to Sayyid Ahmed al-Sharif but to accept the Ottoman-German proposal. ${ }^{69}$ Consequently, Sayyid Ahmed al-Sharif decided to wage war against the British within British-controlled Egyptian territory with the support of the Ottoman Empire and Germany. The attack took place in $1915 .^{70}$

The Libyan leadership of the mujāhidin was well aware of the seriousness of the situation, especially with the presence of the Italians. The German-Ottoman project aimed to encircle the British; the movement of troops from Libya would have a significant role in the defeat of the British in Egypt, especially as the internal situation allowed them to do so after the victories they had achieved against the Italians. At the same time, the Ottoman army move coincided with the Libyan attack to control the Suez Canal. ${ }^{71}$

65 Kāmil, al-Dawlā al-'arabiyya al-kubra, p. 336.

66 Mīkhā'īl, al-'Ālāqāt al-injīliżìyya al-lībiyyā, p. 54

67 De Candole, The Life and Times, p. 26.

68 Hūwīdī, al-Haraka al-wațanìyya fì sharq Lìbiyā, p. 66.

69 al-Zāwī, Jihād al-abțāl, p. 256.

70 Ismā'îl, Tārīkh Afrīqiyà al-ḥadìth, p. 453.

71 Hagen, Die Türkei im Ersten Weltkrieg, p. 19. 
Sayyid Ahmed al-Sharīf and Nuri Bey led the mujāhidīn forces in this war. All were motivated by the main aim of ending the Italian occupation in their land using the aid of the Germans and the Ottomans, who promised to declare the independence of Libya if they won the war against the Italians. Moreover, the mujāhidin believed in the idea of jihad and its success in fighting the occupiers. ${ }^{72}$ The choice of battle location depended on the strategy of the site and was sometimes determined by the mujāhidin because they knew the country well. ${ }^{73}$ The first attack was on Sallum, a village on the Egyptian-Libyan border at the beginning of November $1915,{ }^{74}$ where the militants managed to achieve a victory over the British forces. In conjunction with the start of the ground attack, the German submarine U35 made some military movements that led to the destruction of the British aid ship Tara in the Mediterranean Sea. ${ }^{75}$ The German support to the mujāhidin was highly effective, confirmed by the success of the German submarine in sinking that ship in the Gulf of Sallum on November 5, 1915. This resulted in the capture of the captain of the ship, one officer, and 79 soldiers who were on board and taken to Libyan territory, specifically to the Gulf of Bardia, where they were handed over to the Ottomans as war prisoners (see Appendix 7). ${ }^{76}$ The maneuvers of the German submarines did not stop; the same submarine was able to destroy two other boats in the port of Sallum carrying guns to support the land army. ${ }^{77}$ Sayyid Ahmed al-Sharif did not play a real role in the attack. The mujāhidin themselves planned and implemented the attack after hearing the news that their leaders had agreed to this project. The presence of Nuri Bey in the region also supported their situation. ${ }^{78}$

\section{Umalrakham Battle in 1915}

The German submarine U38, led by Captain Valentiner, reached the eastern shores of Libya on December 12, 1915. The German Consul and a Turkish officer named Jamal were on board, accompanied by two Arab leaders; the ship was

72 Ahmida, Ali Abdellatif, Forgotten Voices, Routledge, London, 2005, 108p.

73 Hūwīdī, al-Haraka al-wațanīyya fì sharq Lìbiyā, pp. 74, 76.

74 Brūkilmān, Tārīkh al-shu'ūb al-islāmīyya, p. 652; Lūtiskī, Tārīkh al-aqțār al-'arabiyya alḥadīth, p. 372; Ziyāda, Lìbiyā fĩ al-'ușūr al-hadìthā, p. 87.

75 'Azzām, "Kifāḥ al-sha'b al-lībī fî sabīl al-ḥurrīyya”, p. 432; al-Sāḥlī, "Wamaḍāt min al-wathā’iq al-'ūthmānīyyā”, p. 323.

76 De Candole, The Life and Times, p. 27.

77 U-Boote der Kaiserlichen Marine an der Libyschen Küste 1915-1918, p. 1.

78 Hūwīdī, al-Haraka al-wațanìyya fī sharq Lìbiyā, p. 66. 
also carrying 6 tons of munitions destined to the mujāhidin to support them in continuing the fight against the British. ${ }^{79}$ The area of Umalrakham, located near Matrouh in Egypt, was where the first clash between the forces of the Libyan mujāhidīn and a number of volunteers from the tribe of 'Aūwlad 'Alī on the one side, and the British on the other, took place. The battle lasted from morning until evening, but the mujāhidin persevered and suffered minor losses, while the British lost many soldiers. ${ }^{80}$ After the end of the battle, the British retreated and the mujāhidīn withdrew to the area of Wadi Majid.

\section{Wadi Majid Battle in 1915}

A second battle between the two sides took place at the end of December 1915, in the area of Wadi Majid in Egypt. ${ }^{81}$ The British army received reinforcements and military support represented by the arrival of 15.000 troops to the battlefield. In contrast, the Turkish commander Jā'far al-'Askarī arrived as the head of a group of troops to rescue the mujāhidinn, while Nuri Bey led the battle. Nuri defeated the British, forcing them to withdraw toward Matruh in Egypt after they suffered extensive losses. ${ }^{82}$

\section{Bir Tunis Battle in 1916}

Bir Tunis was located near Bir Majid in Egypt, where the Libyan mujāhidīn got their supply of water. The British wanted to end the war quickly and to eliminate the Libyan forces. So, they decided to mount a surprise attack, but natural factors had a role in delaying it. There was heavy rainfall that impeded the movement of the British army and thus delayed the start of the battle between the two parties in Botons to late January 1916. Sayyid Ahmed al-Sharif participated in this battle, in addition to Nuri Bey and some German officers who took part in the fighting. The losses of the two parties were large. ${ }^{83}$ Despite the small number of mujāhidinn, the result was in their favor. The fact that a German officer was among the dead led the British to assert that the senior leadership and management of the battle

79 U-Boote der Kaiserlichen Marine an der Libyschen Küste 1915-1918, p. 1.

80 Hūwīdī, al-Ḥaraka al-wațanìyya fì sharq Lìbiyā, p. 73.

81 De Candole, The Life and Times, p. 28.

82 See Microfiche Copex HDP13, LOS 4, Asw A-+, Politisches Archiv WK Nr. 38, 1. Februar 1916.

83 Hūwīdì, al-Haraka al-wațanìyya fĩ sharq Lìbiyā, pp. 77-78. 
had been performed by the German. Rather, this was because of the nature of the battle and the stead fastness of the mujāhidinn. However, there was no question that most participants were Libyan mujāhidin who were motivated by the ideology of jihad and the goal of expelling the Italian occupation from their country. After this battle, more officers and soldiers were sent by the Ottoman Empire to eastern Libya. Although the document does not specify numbers, it does record that submarine U38 brought 6 officers and a load estimated at 10 tons of weapons to the of King Idris on February 10-11, 1916. The submarine was unloaded at the port of Bardia. ${ }^{84}$

\section{Controlling Siwa Oasis in 1916}

Following these clashes near the coast, Ahmed al-Sharif commanded the mujāhidin to distribute their forces and not to be concentrated on one front. This was why he sent the Egyptian Captain Mohammad Șaleh Harb to Siwa Oasis. ${ }^{85}$ He succeeded in controlling the oasis and dominated the neighboring area. In addition, he controlled the area of Farafra Aldakhila. After this success deep in Egyptian territory, a military contingent was led by 'Abd al-llāh Tamaskat to the Bahriyya oasis, where he defeated the British garrison and controlled the provinces of Fayoum and Minya. ${ }^{86}$ The intensification of fighting between the Libyan mujāhidin and the British and the losses on both sides prompted Germany to intensify its financial and military support. This was reflected by the arrival of the German officer Paul Freiherr Wolff von Todenwarth ${ }^{87}$ with his companions, in addition to four Turkish officers along with ammunition and weapons on April 20,1916 on board submarine U21. ${ }^{88}$

84 U-Boote der Kaiserlichen Marine an der Libyschen Küste 1915-1918, p. 2.

85 Mīkhā'îl, al- 'Ālāqāt al-injìlizzìyya al-lībiyyā, p. 61.

86 'Azzām, "Kifāḥ al-sha'b al-lībī”, pp. 434-435.

87 Halpem, Paul G., The Naval War in the Mediterranean: 1914-1918, Routledge, London, 2016, 630, p. 246.

88 U-Boote der Kaiserlichen Marine an der Libyschen Küste 1915-1918, p. 2. 


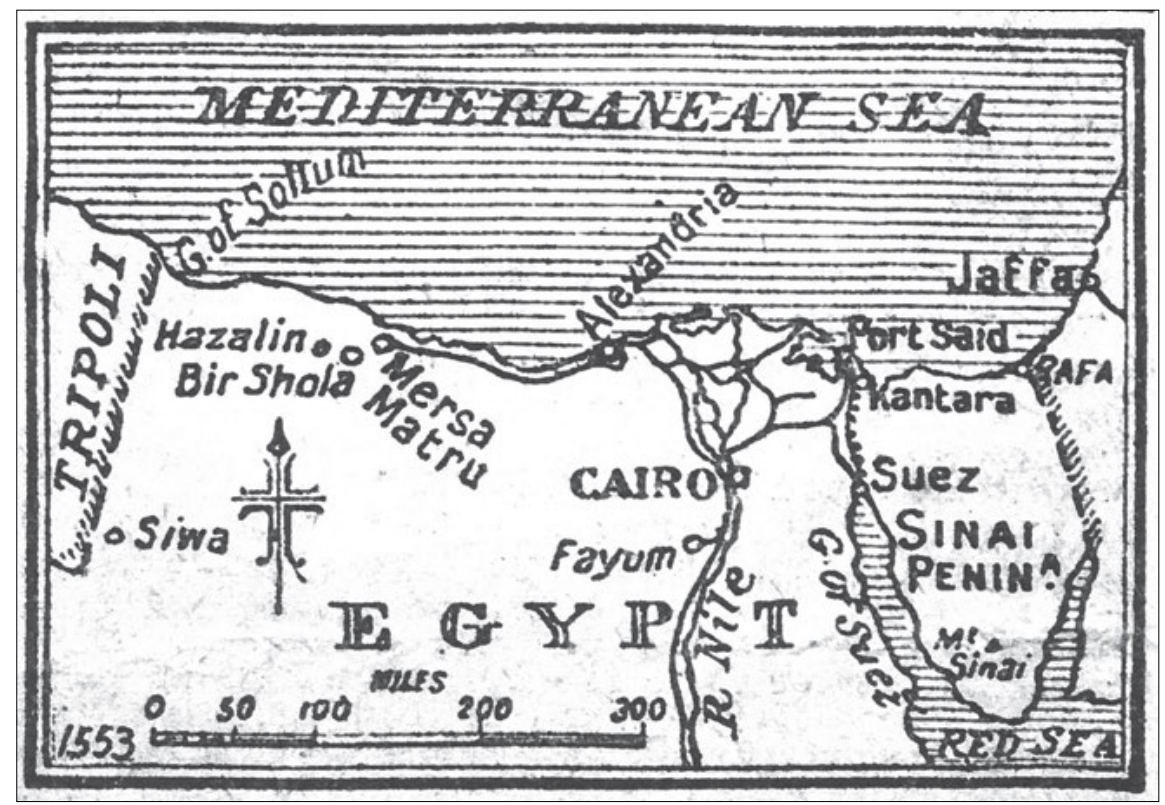

Map 9: Battle to control Siwa Oasis in 1916, Libyan-Egyptian border provinces and places of battles during World War I

\section{The Second Battle of Majid in 1916}

After the arrival of more military reinforcements, the Libyan mujāhidin continued their war against the British. The next clash between the two sides was at the second battle of Majid. Jā'far al-'Askarī led the forces in this battle, while General Wallace led the British. The British suffered losses again in spite of the small number of mujāhidin who forced them to withdraw from the battlefield. The advance of the northern unit of the Senusi-army through the coastline stretch, which was cleared by the English east of Sellum up to east of Nedjaila, was coming to a stop near Majid. Small skirmishes had been taking place close to Umm-er-Rham and Majid. Afterwards, the English attacked on December $26^{\text {th }}$ with superior forces; they were very well equipped both in terms of weapons and men. Jā' far held position with only 40 men. Given the superior forces of the English, they would have hardly changed much in the outcome of the skirmish. ${ }^{89}$ 


\section{Agagia Battle in 1916}

Agagia (also Agagiya or Aqqaqiya) was located near the coast of the Mediterranean and the battle ensued between the two sides there. The mujāhidin, in particular the forces under the command of Nuri Bey, were suffering of a severe shortage of supplies and ammunition. In contrast, the British army had received reinforcements and supplies, which is why they won the battle. It should be noted that 'Abd al-Raḥmān'Azzām was involved in this battle. ${ }^{90}$ It led to great losses for the mujāhidin and they were forced to withdraw from the battlefield. Moreover, most of the forces that participated in the fighting withdrew from Egyptian territory toward Cyrenaica, within Libyan territory. ${ }^{91}$ This gave the British a chance to move forward. They succeeded in taking control of the region of Sidi Barrani on February 28, $1916^{92}$ and then occupying Sallum on March 24, 1916. ${ }^{93}$ Sayyid Ahmed al-Sharif, along with Mohammad Șaleh Harb, was able to seize most of the Egyptian oases, i.e. Farafra, Dakhla, al-Kharija and the Bahria. ${ }^{94}$ They succeeded in tightening their grip on the road to the oases, implementing the agreement between the Germans and the Ottomans, which also required the sparking of a revolution in Egypt led by Ahmed Jamal against the British. This was supposed to be synchronized with the arrival of Ottoman forces coming from Syria to the Suez Canal to encircle the British; however, this plan failed. ${ }^{95}$ The British managed to control the interior territories of Egypt and thoroughly repressed the revolution. Thus, Ahmed Jamal could not carry out his task of enabling Ottoman penetration via the Suez Canal by diverting British attention toward the eastern border and internal unrest. ${ }^{96}$ This was despite careful preparation and the assistance by German officers, ${ }^{97}$ in addition to the approximately 3.500 troops who were supposed to perform this task. Britain succeeded in repelling the attack of the Ottoman Empire after the success of the Ottoman army in moving overland across the Sinai Desert toward Ismailia. The Ottomans began to withdraw. That was how the German-Ottoman plans to control that front failed. ${ }^{98}$

90 Hūwīdī, al-Ḥaraka al-wațanīyya fī sharq Lībiyā, pp. 82-83; 'Azzām, “Kifāḥ 'al-sha'b al-lībī”, pp. 438, 441, 443.

91 Hūwīdī, al-Haraka al-wațanīyya fī sharq Lìbiyā, pp. 82-83.

92 Ibid., p. 86.

93 Kāmil, al-Dawlā al-'arabiyya al-kubra, p. 338.

94 Mīkhā'īl, al-'Ālāqāt al-injìlizzìyya al-lībiyyā, p. 62.

95 Brūkilmān, Tārīkh al-shu'ūb al-islāmīyya, p. 604; Mannā', Ahmed al-Sharīf, p. 70.

96 Hūwīdī, al-Haraka al-wațanīyya fī sharq Lìbiyā, p. 95.

97 al-'Aqād, Lìbiyā al-mu'âșira, p. 19.

98 'Atīq, Wajīh 'Abd al-Ṣādiq, Muḥạḍarāt fī tārīkh al-'arab al-mu' āṣir, Dār al-thaqāfā al-'arabiyya, al-Qāhira, 1994/1955, p. 20. 


\subsection{Libyan Defeat in Egypt and German Policy}

Following these dangerous developments, Sayyid Aḥmed al-Sharif and his army in the Egyptian oases became isolated from any contact with the rest of the front. This became worse with a cholera outbreak among the soldiers. Sayyid Ahmed al-Sharif was forced to withdraw his troops toward Siwa, Farafra and Bahria, ${ }^{99}$ where he was attacked by the British in a battle on February 28, 1917. This forced him to retreat toward Libyan territory, ${ }^{100}$ where he arrived with his forces in the areas near al-Jaghbub. They were pursued by the British forces, which wanted to eliminate the troops of Sayyid Ahmed al-Sharif, which resulted in a battle between the two sides in the region of Guba. However, the British failed to defeat the mujāhidin, who were helped by natural factors to avoid more deaths and losses. This battle was the last between the two parties. ${ }^{101}$ However, the British were not satisfied, and sent a warning to Sayyid Idris al-Sanūsī, who was in alJaghbub, to leave the area as soon as possible. They informed him that if he did not, the British forces would fully destroy the city of al-Jaghbub in addition to the burial place of Sayyid Mohammad bin Ali al-Sanūsī. This place was of central emotional and religious significance to the al-Sanūsìyya movement and its loss or destruction would be a great blow. ${ }^{102}$ Upon hearing this threat, Sayyid Ahmed al-Shariff decided to leave the area. He went toward the al-Agalia area. ${ }^{103}$

Military operations around the desert oases continued between 1916 and early 1917. The fighting coincided with the arrival of German submarines. In July 1916, submarine U39 arrived, carrying two military missions from the Turkish army with ammunition and equipment. It had first docked in the port of Barqa on July $8^{\text {th }}, 1916$ and then went to the city of Misurata on July 10, 1916. The submarine itself returned in October carrying Turkish officers and weapons to support the combat capability of the Libyans. ${ }^{104}$ The submarine was carrying orders for General Todesfarth to return to Germany. ${ }^{105}$ Ottomans suffered in this campaign. Officers and soldiers who took part in the fighting did not leave Libya. They ini-

99 al-Tilīsī, Ba'd al-qurḍabīyya, p. 456.

100 al-Zāwī, Jihād al-abțāl, p. 257.

101 Hūwīdì, al-Haraka al-wațanìyya fī sharq Lìbiyā, p. 94.

102 Shukrī, al-Sanūsīyya dīn wa dawlā, p. 288.

103 Kāmil, al-Dawlā al-'arabiyya al-kubra, p. 338.

104 The Germans did not focus on the support of the Libyan mujāhidin in war only, but they also provided them with food to fight against the widespread hunger in Cyrenaica at the time. For more information, see Microfiche Copex HDP13 in IA - Weltkrieg WK Nr. 114, R21284-2, Bd. 2, 31. Dezember 1916, held in the Politisches Archiv des Auswärtigen Amts.

105 U-Boote der Kaiserlichen Marine an der Libyschen Küste 1915-1918, p. 2. 
tially remained in the city of Ajdabiya, and then moved to the city of Misurata. ${ }^{106}$ The reason behind their stay was the insistence on the importance of their presence in the country and that the war was not yet over. Second, Turkey was determined to maintain its control over Libya for as long as possible, and they did not want to lose this geographically important part of the region. That was the reason behind Nuri Bey continuing to work to serve the interests of the Ottoman Empire. His work was focused on the restoration of confidence in Turkey and the revival of Turkish influence, in addition to control over the Turkish military. Nuri Bey tried to be closer to the new political leadership in Cyrenaica led by Idris al-Sanūsī, who ruled from 1917 and did his best to influence them to continue the war against the British in Egypt. He offered great promises to provide aid via German submarines. But the new commander of the Sanūsìyya movement had a different point of view to that of the Ottomans. ${ }^{107}$ Especially after the Sanūsìyya movement's failed attack on Egypt, he believed that the interests of the country required them to enter negotiations with the British and the Italians alike and to not engage with them in an unequal war. From this point, Idris al-Sanūsī decided not to listen to the appeals of the Ottomans and even ended his connection with them. This led to a changed attitude on the part of the Ottomans, who began to regard him and the al-Sanūsìyya movement as opposition.

The new Turkish policy was thus to attack the al-Sanūsīyya movement. Nuri Bey then sent three Turkish officers with their troops to the south of Libya, where Mohammad Abed al-Sanūsī, the brother of Sayyid Aḥmed al-Sharīf, was managing the affairs of the region. The soldiers brought gifts to Mohammad Abed al-Sanūsì to hide their movements and intentions and to reassure the latter that their presence did not hold any other purpose. They then made the sudden move of seizing the city of Murzuq. Mohammad Abed al-Sanūsī tried but failed to recapture the city. In addition, the Ottomans also seized the city of Zwila and continued to hold it, despite the repeated attempts to recover it by the al-Sanūsìyya movement, until July 10, 1917 when the Ottomans withdrew from Murzuq and Zwila. They turned toward the city of Sebha and regrouped there, especially with the arrival of supplies from Nuri Bey in the city of Misurata. This led them to intensify their control over Fezzan to force Mohammad Abed al-Sanūsī to leave it and go to the city of al-Kufra. ${ }^{108}$ The Ottomans controlled Fezzan until the end of World War I. ${ }^{109}$ During this time, the Italian presence was concentrated in the coastal

106 Khishīm, Șafaḥāt min jihādanā al-wațan̄i, p. 73.

107 Hūwīdī, al-Haraka al-wațanìya fī sharq Lībiyā, p. 116.

108 Shukrī, al-Sanūsìyya dīn wa dawlā, pp. 189-190.

109 Hūwīdī, al-Ḥaraka al-wațanìyya fī sharq Lìbiyā, p. 116. 
regions only. Due to their involvement in the war in Europe around this time, they did not undertake large scale military activity in Libya. They did, however, make a few smaller attacks on the mujāhidin when this did not present a great risk to their own side. Within the framework of jihad, the Ottomans not only started the war in Egypt, but also sought to declare war on the French in Tunisia by mobilizing the mujāhidin in the western region. To achieve this goal the Turkish envoy Hassan al-Sharīf traveled to the city of Misurata and met Ramaḍān al-Swìhlī and Saif al-Dīn al-Sanūsī, one of al-Sanūsìyya movement leaders, and offered them the project of attacking the French in Tunis, but they did not agree. Saif al-Dīn al-Sanūsī refused the plan while Ramaḍān al-Swīḥlī accepted it. This led the al-Sanūsī leader to leave the city of Misurata. ${ }^{110}$ Saif al-Dīn al-Sanūsì's point of view was that the country could not bear the burden of fighting three major European countries (Italian, British and French) at one time, especially at this particular time. He was particularly concerned by the financial and economic problems and deteriorating military forces. Despite this, some Ottoman officers attacked the Ben Guerdane area in September 1915 and succeeded in capturing 40 French soldiers. France then moved quickly and decisively addressed the leadership of the al-Sanūsìyya movement to discuss the necessary measures. Saif al-Dīn al-Sanūsī quickly directed a stern warning: The Ottoman officer who was in charge was forced to stop the attack on the French and return to Fezzan. ${ }^{111}$ Germany's role in these events became clear when it commissioned the consul Mannesmann to join the Ottomans in their attack on the western border. However, Saif al-Dīn issued orders banning him from reaching his destination so as not to complicate matters even more. Mannesmann had moved with the Turkish leaders to Misurata after they left Cyrenaica. ${ }^{112}$ The position of the Ottomans at this stage was sensitive, especially given the lack of united rule over Libya. The eastern and southern parts were under the control of the al-Sanūsìyya movement, the center of the country was subjected to the tribal leaders, while the west was disputed. That was the reason behind the attempts by the Ottomans to renew their relationship with Sayyid Ahmed al-Sharif. To show their good intentions, they sent two convoys loaded with food and other supplies that the al-Sanūsìyya movement needed. The convoy should have departed from Misurata, but the leader of Misurata, Ramaḍān al-Swìhlì, refused to permit the passage of these goods to al-Sanūsìyya, due to his own hostile relations with the movement. He took control of the convoy and pre-

110 al-'Aqād, Lìbiyā al-mu'āṣira, p. 21.

111 Shukrī, al-Sanūsīyya dīn wa dawlā, p. 201; see also Martel, André, "La Libye, 1835-1990. Essai de géopolitique historique”, R.E.M.M.M. 59-60, 1991, p. 291.

112 al-Zāwì, Jihād al-abțāl, p. 290. 
vented it from reaching its target. Following these developments and the refusal of Sayyid Ahmed al-Sharif to cooperate politically with the Ottomans, the Turkish commander Nuri Bey distanced himself from the Turkish promises ${ }^{113}$ and decided to leave the territories under al-Sanūsìyya movement influence despite the difficult economic conditions. He retired from the political sphere and refused to enter an armed conflict with his cousin Sayyid Idris al-Sanūsī, who became the leader of the movement and the holder of actual political power in the region of Cyrenaica.

An analysis of the events that occurred reveals that the failure of the war against the British in Egypt was due to a combination of factors. These included the imbalance of power in addition to the fact that the mujāhidin had been fighting for more than three years against the Italians and the al-Sanūsìyya movement was internally divided. As a result of this war, the al-Sanūsìyya movement divided into two groups: the first, a group of supporters that followed its religious and national senses, and led by Sayyid Ahmed al-Sharif, and the second, which took into account the internally difficult situation and led by Sayyid Idris al-Sanūsī, each governed by their own beliefs, opinions and political orientations. In sum, the military campaign against the British in Egypt led to the failure of the Libyan side. They did not make any significant gains on the ground or even political gains, and suffered different types of human and material losses. In spite of all these failures that hit the German-Ottoman plans in eastern Libya, their determination was not weakened in their action in the north of the country. Libya became the focus of the Ottoman-German interests again, which led them to take further practical steps. The first was the arrival of an Ottoman envoy in May 1918 to monitor the situation closely. Then a mission was appointed to Prince Osman Fouad who was appointed commander of the African military forces in Libya by the Ottoman authority. He was to report about everything happening on the ground to the Ottoman authorities to be able to take the necessary measures. He went to Istanbul to present the results of his tour to the powers there and kept in contact with the leaders of jihad in Libya. He wrote to Ahmed Bik al-Marīd, one of the jihad leaders in the city of Terhona, and briefed him on the latest developments, promising him that he worked for the benefit of Libya and would secure all the needed assistance before returning to Libya. ${ }^{114}$ The German submarines took over the transfer of messages between the two sides. The results were very encouraging for the

113 Shukrī, al-Sanūsīyya dīn wa dawlā, pp. 224-225.

114 Wathīqā 11, Risālā min al-'amīr 'Uthmān Fū'ā ilā Ahmed Bik al-Marịd, 2-2-1918, al-Wathā'iq al-ijtimā'īyya, shu'bat al-wathā'iq wa al-makhțūṭāt, al-markaz al-wațanī li-l-wathā'iq wa almāḥafūḍāt al-tārīkhiyya, Tarābulis. 
Ottomans, as they had Misurata as a field of their activity. That was the reason for the return of Prince Osman Fouad to Libya, representing the Turkish side. ${ }^{115}$ The German Paul Freiherr Wolff von Todenwarth was commissioned to resume representation of the German side and to implement the German policy in 1918. ${ }^{116}$ Both leaders arrived and worked on the implementation of the task. The German baron assumed the task of managing the telegraph in Misurata, and therefore was responsible for communication, coordination and command operations, which was a delicate task at that particular stage. It was decided by the Ottomans that Libya was to be the main base of their operations in North Africa. The two sides decided to make a major change in the process of moving the front of Libya. This time, the main emphasis was laid on the extension of the mujāhidin in the west, with better arms and financial support. This decision was issued by German military staff in Berlin, ${ }^{117}$ which sent a letter to the German Ministry of Foreign Affairs on January 4, 1917 to inform them of the plans. ${ }^{118}$ The military leadership sought to implement this plan in Libya, supported by weapons and equipment transported by German submarines from Germany. ${ }^{119}$ The starting point was to be from the west heading east and thus involving the largest possible number of Libyan people. This time, the primary aim of the mujāhidin was to expel the Italian presence from Libya. The Ottomans received assistance from Germany in the delivery of military support to the Libyan jihad in Misurata (see Appendix 4). The Italians tried hard to prevent the arrival of those supplies. For example, the German submarine UC73, led by Commander Schebeler, reached the city of Misurata carrying three Ottoman officers, 1.000 rifles, 200.000 bullets in addition to 18 boxes filled with gold. Bad weather forced the submarine to dock in the Gulf of Sirte, where its cargo was unloaded on May 26, 1917. ${ }^{120}$ The Italian forces tried to take possession of the submarine and even continued in their efforts when it reached the port, but the counter-attack of the mujāhidin forced them to retreat. ${ }^{121}$ This Italian attack came as a reaction against the German forces attacking Italian targets in April 1917. Examples include the German submarine U20 missile attack on an Italian ship in front of the city of Zuwarah in western Libya. They

115 Ibid.

116 Ibid.

117 Ibid.

118 Ibid.

119 Wathīqā 12617, Wathā'iq al-'arshif al-siyāsī al-'almānī, wathā'iq muṣawarā bi-shu'bat alwathā'iq al-ajnabīyya, al-markaz al-wațanī li-l-māḥafūḍāt wa al dirāsāt al-tārīkhiyya, Ṭarābulis. 120 U-Boote der Kaiserlichen Marine an der Libyschen Küste 1915-1918, p. 2.

121 al-Zāwī, Jihād al-abțāl, p. 291. 
also attacked another frigate off the coast of Tripoli and detonated it. ${ }^{122}$ The political action was moving toward reviving the idea (begun in 1914) of establishing the Republic of North Africa. This idea received strong support from Germany, Austria and the Ottoman Empire in 1915. A number of jihad movements established by youth from Tunisia, Algeria and Morocco aimed at jihad against the European occupation participated in these activities. Their aim was also to establish one united republic in North Africa. They aimed to build the republic with political borders starting from the Red Sea in Egypt in the east, to the Atlantic Ocean in the west. They took the Tunisian-Libyan border as the starting point for their activities. Their activities were supported by the German Ministry of Foreign Affairs, which received representatives of this entity and promised them support and assistance. The German ambassador in Istanbul was one of the strongest supporters to this movement. Germany and Austria committed to this movement. Germany provided equipment and weapons. ${ }^{123}$ The internal situation in Libya was very suitable for the development of this scheme because Italian control over the country during this stage was weak and limited to a few coastal cities. Despite this, the Italian administration in Tripoli discovered the scheme. ${ }^{124}$ Despite all these events, German-Ottoman aid to the Libyan mujāhidin did not stop. The reliance on German submarines made the port city of Misurata a vital area for the movement and landing of cargo. ${ }^{125}$ The Germans intensified their activity during 1917, particularly between May and December. In May, a mission from the German army reached the submarine U20, led by Rittmeister Freiherr (baron) v. Todenwarth. The other submarine, UC20, was doing the same during the month of July 1917 and had succeeded in its mission. On July 30, it bombed important Italian military targets in the city of al-Khums near Misurata, the Italians bombed back, which forced the submarine to dive and stay away from the coast. ${ }^{126}$ In October 1917, the submarines attacked Italian targets while at the same time continuing to transfer military support for the Libyan mujāhidin. On October 4, the submarine UC73 transported an estimated 25 tons of military equipment to the city of Misurata and on October 6 attacked the Italian vessel and an Italian protection boat which had been docked in Tripoli with two missiles. On the next day, Italian fortifications in the city of Tripoli were attacked.

122 U-Boote der Kaiserlichen Marine an der Libyschen Küste 1915-1918, p. 2.

123 'Amīsh, al-Tārīkh al-sīyāsī, p. 101.

124 Wathīqā 322/371, al-wathā’iq al-injīlīzīyya, shu'bat al-wathā’iq al-ajnabīyya, al-markaz alwațanī li-l-māḥafūḍāt wa al-dirāsāt al-tārīkhiyya, Ṭarābulis.

125 al-Tilīsī, Ba'd al-qurḍabìyya, p. 12.

126 U-Boote der Kaiserlichen Marine an der Libyschen Küste 1915-1918, p. 3. 
The Ottoman Empire tried in 1918 to reinforce its influence in Libya after the loss suffered in Egypt and the failure of all the Turkish activities inside Libya. Evidence of this is provided by the fact that the Germans were behind the selection of Prince Osman Fouad as a general governor in Libya in 1918 (see Appendix 7) because Germany wanted him to mobilize the mujāhidin to reignite war in Libya. ${ }^{127}$ Germany had offered to provide Turkey with two German leaders to accompany him on his mission. But Enver Pasha rejected the German offer. However, he arrived in Libya accompanied by a number of German experts on board a German submarine. Their field of operation was telecommunications and advisers to Prince Osman Fouad. ${ }^{128}$ In addition, he was assigned the task of reconciling the views of the Ottomans and Sayyid Ahmed al-Sharif. During the negotiation between Germany and Sayyid Ahmed al-Sharīf, he sent Moḥammad Sadiq as his delegate to reach an agreement with the German party. ${ }^{129}$ The fact that Sayyid Ahmed al-Sharif sent a representative to the meeting on his behalf reflected his support for the German project. 'Abd al-Raḥmān'Azzām had fought against the British in Egypt and then returned with Nuri Bey to Libya and remained with him until they left together in early 1918 to Turkey. From there he was sent to Berlin to enter negotiations with Germany to send military equipment to Libya. Therefore, he was well known to the military and political powers in Germany, who approved him to be the companion of Prince Osman on his new mission in Libya. ${ }^{130}$ Despite the departure of Nuri Bey from Libya, the Ottoman government sent a number of leaders to take over and complete the task that he had begun. Ishaq Pasha, an officer in the Ottoman army, was selected as Nuri Bey's replacement as the commander of Ottoman forces on the western front in early 1918. However, unlike Nuri Bey, he did not take Misurata as a center for his leadership, but headed west and settled in the city of Zawiya. A conflict developed between Ishaq Pasha and Ramaḍān al-Swīḥlī over leadership tasks, and Ramaḍān al-Swīḥlī maintained that he was the higher commander. The conflicts intensified over the issue of who should receive the military and financial aid sent by German submarines to Libya. Whilst Ramaḍann al-Swīhlī argued that this aid and ammunition should be kept within the area of influence, the Ottoman commander Ishaq Pasha recommended the transfer of all arms and ammunition to the headquarters at Zawiya, arguing that the western region was the most important field of fighting against the Italians and experienced the most battles

127 Hūwīdī, al-Haraka al-wațanìyya fī sharq Lìbiyā, p. 170.

128 U-Boote der Kaiserlichen Marine an der Libyschen Küste 1915-1918, p. 4.

129 Hūwīdī, al-Haraka al-wațanìy a fī sharq Lìbiyā, p. 168.

130 Shukrī, al-Sanūsìyya dīn wa dawlā, pp. 229, 231. 
and clashes at this time. The conflicts intensified to the extent that the Turkish commander set up a military campaign to force Ramaḍann al-Swịhlì to execute his orders. However, the intervention of Prince Osman Fouad came with positive results and prevented further losses on the side of the mujāhidinn. ${ }^{131}$ At the beginning of 1918, the German submarine continued to assault Italian targets in Libya. For example, submarine UC73 attacked the Italian ships on the coast of the city of Tripoli on January 2, 1918. At the beginning of November 1918, some of these submarines were attacked in Tripoli, making it difficult for them to continue their activities. They had also received orders that the coast where they operated was unsafe. ${ }^{132}$

This period was the end of World War I, when the defeat of Germany had become clear. Accordingly, the field of the military operations developed negatively for the Ottoman Empire and Germany alike. They were defeated by the allies. This was the background to the signing of the Treaty of Modros at the end of October, 1918. ${ }^{133}$ One of the terms of this treaty was that the Ottoman state had to withdraw all armies from all the Arab countries. Based on that, they issued orders to their officers in Libya to abandon military operations against Italy and even surrender to the Italians. They were also obliged to hand over all the ports under their control to the allied armies. ${ }^{134}$ This was the beginning of the end of OttomanGerman relations in Libya, as it was also the start of breaking the link between the Ottomans and Libya, in spite of which Prince Osman Fouad continued to be present in Misurata. ${ }^{135}$ Von Todenwarth was present in Misurata at this time and received the news of the defeat over the radio in October 1918. He received orders to leave Libya, along with Prince Osman Fouad and all the Turkish officers as well as the German who were working with him. He received these orders, but did not carry them out directly. He thought it was wise to postpone the execution of these orders somewhat so they could arrange the political situation in Libya. ${ }^{136}$

During this time, von Todenwarth learned that Germany intended to continue the war until the end, and that they were committed to helping the Libyans with money and weapons. In return, the leaders of jihad in Libya announced their willingness to form a local government to ensure the continuity of the war against the Italians in a united manner. In the meantime, there was a German submarine

131 Hūwīdī, al-Ḥaraka al-wațanìyya fī sharq Lìbiyā, p. 167.

132 U-Boote der Kaiserlichen Marine an der Libyschen Küste 1915-1918, p. 4.

133 Brūkilmān, Tārīkh al-shu'ūb al-islāmìyya, p. 605; 'Amīsh, al-Tārīkh al-siyāsī, p. 63.

134 al-Zāwī, Jihād al-abtāl, pp. 304-305.

135 Wathīqā 54, al-wathā'iq al-ițālīyya, p. 207.

136 'Amīsh, al-Tārīkh al-siyāsī, p. 63. 
docked off the coast of Misurata. ${ }^{137}$ This submarine arrived to take Prince Osman and the German Baron and their officers and soldiers. But they decided to stay and were supported by the commander of the submarine in their decision, who told them that the route was not safe and it was not the right time to travel. Thus, the submarine turned back. The jihad leaders in Libya, Prince Osman, and 'Abd al-Raḥmān 'Azzām held an emergency meeting to take the appropriate decision in line with the dangerous developments.

Prince Osman sent an invitation to all tribal leaders to come to Mislata for a meeting, which took place in the city of Mislata in 1918 and concluded with the declaration of the Republic of Tripoli. ${ }^{138}$ The republic included all tribal leaders and dignitaries in the western region of the country. This stage was particularly critical because Germany and the Ottoman Empire had withdrawn from the conflict, which meant the end of military supplies and equipment for the mujāhidīn ${ }^{139}$ essential for their struggle against the Italians. This made the role of local fighters even more crucial. The local leaders had a prominent role in the events that occurred during the final phase of World War I, particularly in the central and western regions of Libya. They included Sulaymān al-Bārūnī, who took leadership in the western region, Ramaḍān al-Swìhilī, who had an alliance with the Italians and fought against the al-Sanūsīyya movement, and 'Abdul Nabī Bilkhīr, who was the leader of the Warfalla tribe in the area of Bani Walid in the north-west of Libya, who had also collaborated with the Italians, and Ahmed Bik al-Marīẹ, the leader of the Tarhuna tribe in the southeast. The idea of proclaiming the Republic of Tripoli was an extension of the idea of the Republic of North Africa, which had been adopted and supported by Germany during the early years of World War I. At this stage, Germany also supported this idea, but on a small scale. It was seeking to achieve political gains after its defeat in the war. The leaders of the Republic of Tripoli wanted to obtain international recognition. They sent messages to Britain, France, Italy and the United States to this end but their efforts did not achieve the desired results. ${ }^{140}$ However, they kept their contact with Italy independently and succeeded in signing an agreement with it in 1919. The direct result was the immediate issuance of a basic law for Tripoli, by which the Libyans could form a parliament in the presence of a governor to be appointed by the king of Italy. ${ }^{141}$ With the defeat of Germany and the Ottoman Empire and the actual withdrawal

137 U-Boote der Kaiserlichen Marine an der Libyschen Küste 1915-1918, p. 4.

138 al-Zāwī, Jihād al-abtâl, pp. 310-311.

139 'Amīsh, al-Tārīkh al-siyāsī, p. 63.

140 al-Ḥasan, al-Anzima al-sīyāsiyya wa al-distūriyya, p. 390.

141 Ibid., pp. 390-391. 
of all officers from Libya in 1919, the Ottomans were subjected to strong pressures by the allied powers and forced to sign a number of treaties that led to the end of their influence and the despoiling of large territories that were under their control. This deteriorating situation led Muștafa Kemal Atatürk (ruled 1881-1938) to declare a Turkish secular state when he separated the sultanate and caliphate. He then canceled the sultanate and announced the republic in October $1923 .{ }^{142}$ At that time, Germany had elected a new government called the Weimar Republic.

These international events greatly affected German policy toward the Mediterranean countries in general and Libya in particular, as the latter had been at the heart of German policy in this area during World War I.

142 Waḥīd, al-Qawl al-mufīd fĩ ḥukum al-sulțān 'Abdul-Ḥamīd, p. 307. 